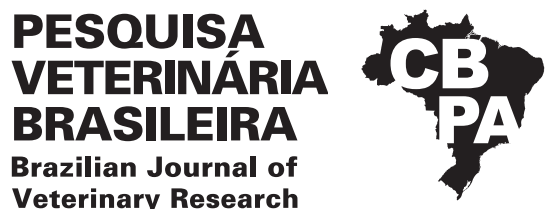

Pesq. Vet. Bras. 40(4):254-260, April 2020 DOI: 10.1590/1678-5150-PVB-6510

Original Article Livestock Diseases

ISSN 0100-736X (Print)

ISSN 1678-5150 (Online)

\title{
Infectious diseases dynamics in growing/finishing pigs in Southern Brazil (2005-2016) ${ }^{1}$
}

\author{
Guilherme Konradt ${ }^{2,3}$ (D), Daniele M. Bassuino ${ }^{2,3}$ (D) Lucas C. Siqueira ${ }^{3}$ (D), \\ Matheus V. Bianchi ${ }^{2}$ (D) Luciana Sonne ${ }^{2}$ (D) David Driemeier $^{2}$ (D) and Saulo P. Pavarini ${ }^{2 *}$ (D)
}

\begin{abstract}
Konradt G., Bassuino D.M., Siqueira L.C., Bianchi M.V., Sonne L., Driemeier D. \& Pavarini S.P. 2020. Infectious diseases dynamics in growing/finishing pigs in Southern Brazil (2005-2016). Pesquisa Veterinária Brasileira 40(4):254-260. Setor de Patologia Veterinária, Departamento de Patologia Clínica Veterinária, Faculdade de Veterinária, Universidade Federal do Rio Grande do Sul, Av. Bento Gonçalves 9090, Porto Alegre, RS 91540-000, Brazil.E-mail: saulo.pavarini@ufrgs.br

This study aimed to determine the frequency and distribution of infectious diseases diagnosed through necropsy examination and histopathological analysis in growing/finishing pigs along 12 years (2005-2016) in Southern Brazil. We evaluated 1906 anatomopathological exams of pigs at growing/finishing phases, of which the infectious diseases corresponded to $75.6 \%$ of the cases $(1,441 / 1,906)$. Porcine circovirus type 2 (PCV2) infections were the most frequent, accounting for $51.3 \%$ of the cases $(739 / 1,441)$ with a higher frequency from 2005 to 2007, characterizing an epidemic distribution, with a gradual decline after 2008. Infectious diseases affecting the respiratory system were the second major cause with $30.1 \%$ of the cases. Among these, necrotizing bronchiolitis caused by swine Influenza $(15.1 \%, 218 / 1,441)$ and bacterial pneumonia $(15 \%, 216 / 1,441)$ were the main conditions. Influenza was mostly diagnosed from 2010 to 2013 , accounting for $43.1 \%(167 / 387)$ of the cases. After this period, both respiratory infectious diseases were endemic. Digestive system infectious diseases accounted for $10.5 \%$ of the diagnoses $(151 / 1,441)$, with the following main conditions: Salmonella spp. enterocolitis (43.7\%, 66/151), Lawsonia spp. proliferative enteropathy $(41.7 \%, 63 / 151)$, and Brachyspira spp. colitis $(14.6 \%, 22 / 151)$. The latter had a higher incidence from 2012 to 2014 with all cases detected in this period. Polyserositis and bacterial meningitis represented, respectively, 5.8\% (84/1,441) and 2.3\% $(33 / 1,441)$ of the cases diagnosed, with a constant endemic character.
\end{abstract}

INDEX TERMS: Infectious diseases, growing pigs, finishing pigs, Brazil, swine diseases, porcine circovirus, swine influenza, bacterial pneumonia, enterocolitis, polyserositis.

\begin{abstract}
RESUMO.- [Dinâmica de ocorrência das doenças infecciosas em suínos nas fases de crescimento e terminação no sul do Brasil (2005-2016).] 0 objetivo deste estudo consistiu em determinar a frequência e a distribuição das doenças infecciosas diagnosticadas através de exame de necropsia e análise histopatológica em suínos nas fases de crescimento/ terminação ao longo de 12 anos (2005-2016) no sul do Brasil.
\end{abstract}

\footnotetext{
${ }^{1}$ Received on September 26, 2019.

Accepted for publication on October 13, 2019.

${ }^{2}$ Departamento de Patologia Clínica Veterinária, Setor de Patologia Veterinária, Faculdade de Veterinária, Universidade Federal do Rio Grande do Sul (UFRGS), Av. Bento Gonçalves 9090, Porto Alegre, RS 91540-000, Brazil. *Corresponding author: saulo.pavarini@ufrgs.br

${ }^{3}$ Universidade de Cruz Alta (Unicruz), Rod. Municipal Jacob Della Méa Km 5.6, Parada Benito, Cruz Alta, RS 98005-972, Brazil.
}

Foram avaliados 1906 laudos anatomopatológicos de suínos nas fases de crescimento/terminação, dos quais as doenças infecciosas corresponderam a 75,6\% (1441/1906) do total. As infecções por circovírus suíno tipo 2 (PCV2) foram as mais frequentes, contabilizando 51,3\% (739/1441) dos casos, com uma alta frequência de 2005 a 2007 caracterizando uma distribuição epidêmica neste período, e um declínio gradual após o ano de 2008. A segunda principal causa incluiu as doenças infecciosas que afetam o sistema respiratório $(30,1 \%$ dos casos). Dentre essas, destacaram-se a influenza suína $(15,1 \% ; 218 / 1441)$ e pneumonias bacterianas $(15 \%$; 216/1441). O diagnóstico de influenza apresentou uma frequência elevada de 2010 a 2013 , totalizando $43,1 \%$ (167/387) dos casos. Após este período, ambas doenças infecciosas respiratórias exibiram caráter endêmico. As 
doenças infecciosas do sistema digestório totalizaram 10,5\% (151/1441) dos diagnósticos, com as seguintes principais condições: enterocolite por Salmonella spp. (43,7\%; 66/151), enteropatia proliferativa por Lawsonia spp. (41,7\%; 63/151) e colite por Brachyspira spp. (14,6\%; 22/151). A colite por Brachyspira spp. apresentou uma alta incidência de 2012 a 2014 com todos os casos detectados no período. As polisserosites e meningites bacterianas representaram 5,8\% (84/1441) e 2,3\% (33/1441) dos casos diagnosticados, respectivamente, com um caráter endêmico constante.

TERMOS DE INDEXAÇÃO: Doenças infecciosas, suínos, fase de crescimento, fase terminal, Brasil, doenças dos suínos, circovirose suína, influenza suína, pneumonias bacterianas, enterocolites, polisserosites.

\section{INTRODUCTION}

Swine industry represents an important economic activity in Brazil, which has a worldwide leading position in pig production and export (Brasil 2018). Pig health is one of the main challenges in swine industry and it represents, along with biosecurity measures, one of the main focus to improve productivity (Amaral et al. 2006, Sobestiansky \& Barcellos 2012). In this context, infectious diseases (ID) have a direct impact in mortality indexes, as well as it may cause losses in alimentary conversion in finishing pigs (Maes et al. 2003, Neumann 2012). Porcine circovirus type 2 associated disease (PCV-SD) is one of the main conditions affecting swine health (Segalés 2012), with mortality indexes ranging from 4 to $20 \%$ (Segalés et al. 2005, Segalés 2012). Besides this condition, porcine respiratory disease complex (PRDC) causes substantial sanitary impacts in swine industry (Schaefer et al. 2013), with a myriad of viral and bacterial pathogens involved. Primary infectious agents, which are able to induce severe respiratory/lung lesions, are included among these causes, as well as secondary/opportunistic infectious agents, which are mainly related to noninfectious cofactors at the swine farms (Opriessnig et al. 2011). Among these, swine influenza A, Mycoplasma hyopneumoniae, Actinobacillus pleuropneumoniae, Glaesserella (Haemophilus) parasuis, and Pasteurella multocida are the main agents involved (Opriessnig et al. 2011, Schaefer et al. 2013). Nevertheless, digestive system diseases are also highlighted at this phase, with Lawsonia spp. proliferative enteropathy, swine salmonellosis, and swine dysentery as the main conditions involved. These are often related to profuse diarrhea, with similar clinical-pathological findings, and a frequency of occurrence of $19.56 \%, 6.52 \%$, and $4.36 \%$, respectively (Suh \& Song 2005, Kich \& Cardoso 2012, Viott et al. 2013, Burrough 2016). This study aimed to determine the frequency and distribution of infectious diseases diagnosed through necropsy examination and histopathological analysis in growing/finishing pigs along 12 years (2005-2016) in Southern Brazil.

\section{MATERIALS AND METHODS}

A retrospective study of ID affecting growing/finishing pigs (age range of 63 to 160 days) was conducted in the anatomopathological database of the veterinary pathology laboratory from January 2005 to December 2016. The necropsy and anatomopathological protocols were reviewed, and information contained within these reports was registered. These were later classified regarding the diagnosis, annual distribution, and seasonal occurrence. All pigs were originated from farms located in Southern Brazil (Rio Grande do Sul, Santa Catarina, and Paraná states), and were raised in growing-finishing units with variable herds of 200 to 5,000 pigs. Cases with a conclusive diagnosis (obtained through histopathological, immunohistochemical, or Warthin-Starry histochemical exams) were grouped into eight categories of ID: porcine circovirus type 2 infections, swine influenza A infection, bacterial pneumonias, polyserositis, Salmonella spp. enterocolitis, Lawsonia spp. proliferative enteropathy, Brachyspira spp. colitis, and bacterial meningitis. Cases wherein epidemiological, clinical, or pathological data were scarce to obtain a final diagnosis were excluded from this study. Moreover, materials obtained from scientific experiments, abattoirs analysis, and locations outside the scope of this study were excluded of the analysis. Distribution, frequency, and seasonal occurrence of the ID were evaluated and determined through a descriptive statistical analysis. This analysis was represented as $\mathrm{n}(\%)$ for the frequency of diseases diagnosed along the years. A contingency analysis was used to evaluate an association between categorical variables (disease and affected system) along the years. A p-value $<0.05$ was considered statistically significant. All analysis were performed with the Software Jmp 14 (SAS, Cary/NC).

\section{RESULTS}

A total of 1,906 anatomopathological exams of growingfinishing pigs in Southern Brazil were evaluated in this study. Among these, ID corresponded to $75.6 \%$ of the diagnoses $(1,441 / 1,906)$. All cases were from samples originated in the Southern Brazil, mainly represented by Rio Grande do Sul state with $44.6 \%$ of the cases $(643 / 1,441)$, followed by Santa Catarina state with $42.3 \%(610 / 1,441)$, and Paraná state with $13.1 \%(188 / 1,441)$ of the cases.

Porcine circovirus type 2 (PCV2) infections were the most frequent and accounted for $51.3 \%$ of the ID $(739 / 1,441)$, of which $88.6 \%$ were associated with PCV-SD, followed by porcine dermatitis and nephropathy syndrome (PDNS) in $11.4 \%$ of the cases (84/739). PCV2 infections had a higher frequency from 2005 to 2007 , with $54.7 \%$ of the diagnoses during this period (404/739), and, thus, an epidemic distribution was observed. Later on, there was a gradual decline after 2008, until it reached an endemic status. A seasonal occurrence was not observed ( $\mathrm{p}>0.1$ ) either for spring/summer $(358 / 739)$ or autumn/winter (381/739). The annual distribution for PCV2 infections is shown in Figure 1.

ID that affected the respiratory system accounted for $30.1 \%$ of the cases. These were mostly represented by necrotizing bronchiolitis caused by swine influenza A infection, which accounted for $15.1 \%$ of the ID in this study and represented almost $50 \%$ of the pneumonia samples. This condition, which was initially diagnosed by the end of 2009 , had an epidemic distribution with an increased frequency of diagnosis from 2010 to 2013 , accounting for $43.1 \%$ of the cases (167/387). After this period, the disease occurred with an endemic character along with other bacterial pneumonia. Similarly, these accounted for $15 \%$ of the ID $(216 / 1,441)$ diagnosed, in which $79.6 \%$ of the cases $(172 / 216)$ were compatible with suppurative bronchopneumonia, while $20.4 \%$ (44/216) were compatible with fibrinonecrotizing pleuropneumonia. Both conditions (necrotizing bronchiolitis by swine influenza A and bacterial pneumonia) did not vary along the distinct seasons. 


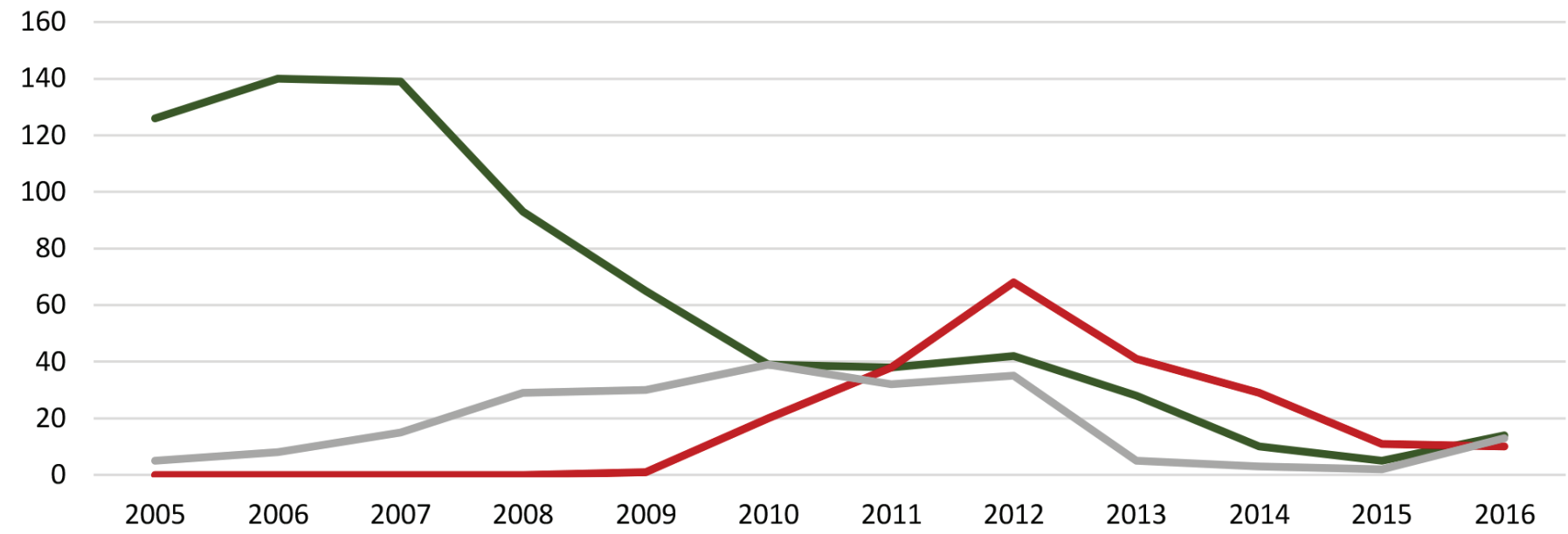

Porcine circovirus type 2 infection $\longrightarrow$ Swine influenza A Bacterial bronchopneumonia

Fig.1. Annual distribution of porcine circovirus type 2 infection, swine influenza A infection, and bacterial bronchopneumonia along 12 years (2005-2016) in Southern Brazil.

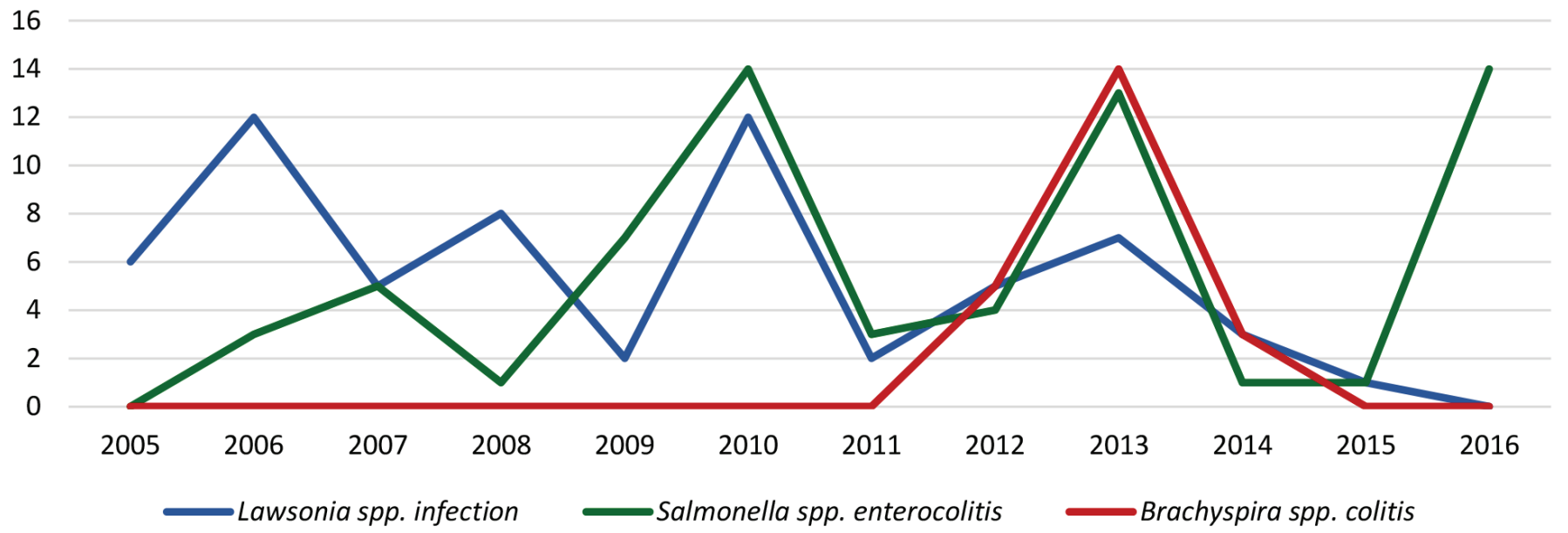

Fig.2. Annual distribution of Lawsonia spp. proliferative enteropathy, Salmonella spp. enterocolitis, and Brachyspira spp. colitis along 12 years (2005-2016) in Southern Brazil.

Moreover, an etiology for bacterial pneumonias could not be determined as these samples were previously fixed in $10 \%$ formalin. The annual distribution for swine influenza A and bacterial pneumonia is shown in Figure 1.

ID affecting the digestive system accounted for $10.5 \%$ of the cases $(151 / 1,441)$. The most common conditions were: Salmonella spp. enterocolitis (43.7\%, 66/151), Lawsonia spp. proliferative enteropathy $(41.7 \%, 63 / 151)$, and Brachyspira spp. colitis (14.6\%, 22/151). Salmonella spp. enterocolitis and Lawsonia spp. proliferative enteropathy had an endemic character distribution in this study, with a higher frequency in 2010, 2013, and 2016. On the contrary, Brachyspira spp. colitis had a higher frequency from 2012 to 2014, with all cases diagnosed within this period. Additionally, Brachyspira spp. colitis had a tendency for seasonal occurrence $(\mathrm{p}=0.08)$, with $68 \%$ of the cases (15/22) diagnosed during spring/ summer. The annual distribution of ID affecting the digestive system is shown in Figure 2.
Polyserositis accounted for $5.8 \%$ of the cases $(84 / 1,441)$, and it occurred with an endemic character along all the analyzed period. Seasonal occurrence was not observed. Bacterial suppurative meningitis represented $2.3 \%$ of the cases diagnosed $(33 / 1,441)$, which had an endemic distribution along the analyzed years. The pathological findings consisted of suppurative meningitis involving the leptomeninges (29/33), and in 4/33 of the cases, besides the leptomeningeal lesions, there were also pleuritis and suppurative pericarditis.

\section{DISCUSSION}

Swine ID affecting growing-finishing pigs accounted for $75.6 \%$ of the cases diagnosed in general, which is slightly above the data reported previously by Brum et al. (2013) in Brazil (68.1\%) and below the data reported by Pelliza et al. (2007) and Tateyama et al. (2000), with 77.2\% and 90\% in Argentina and Philippines, respectively. The highest number of ID in the 
present study may have been influenced by the type of samples analyzed, since this investigation was conducted with fixed samples submitted to a pathology laboratory. Noninfectious diseases affecting growing-finishing pigs, such as gastric ulcers and mesenteric torsions/volvulus, are not often submitted for analysis, because these conditions are easily diagnosed at the gross examination (Morés 2009).

PCV-SD was initially described in 1991 in western Canada, wherein it was associated with postweaning multisystemic wasting syndrome (Allan \& Ellis 2000). Since then, it has been widely described (Opriessnig et al. 2007, Gillespie et al. 2009, Ciacci-Zanella et al. 2015, Konradt et al. 2018), and it was the most frequently diagnosed condition in the current work, accounting for $51.3 \%$ of the cases. These were mostly diagnosed between 2005 and 2007, similarly to previous studies (Opriessnig et al. 2007, Gillespie et al. 2009). After commercial vaccines containing subunits of PCV2 expressed in baculovirus were employed and noninfectious cofactors were reduced, there was a significant decay of the disease in Brazil (Ciacci-Zanella et al. 2015), which was also observed in this study after 2008, when the condition passed to occur with an enzootic character. Therefore, since commercial available vaccines (effective against PCV2 infections) were introduced, there was a marked reduction in PCV associated disease in brazilian swine herds (Ciacci-Zanella 2017).

Respiratory infections in pigs may result in significant economic losses to the production systems, aside from causing negative effects on animal welfare (VanAlstine 2012). These conditions are usually multifactorial and associated with the interaction between multiple infectious agents, as well as noninfectious cofactors, such as environmental, handling, age, genetics, and nutrition (Rech et al. 2018). Swine influenza, which was the main respiratory condition diagnosed in the present study, stood out in Brazil after the human pandemic influenza took place in 2009 concomitantly with a similar clinical disease in pigs, which was caused by similar viral subtypes to the worldwide distributed (Hofshagen et al. 2009, Howden et al. 2009, Pasma \& Joseph 2009, Moreno et al. 2010, Pereda et al. 2010, Schaefer et al. 2011, Watanabe et al. 2012, Njabo et al. 2012, Holyoake et al. 2011). Similarly, in the present study there was a higher frequency of diagnosis between 2010 and 2013, with indexes that reached $43 \%$. This fact may be explained by viral introduction in naïve swine herds to influenza; therefore, the disease had an epidemic character, with higher morbidity indexes (Van Reeth et al. 2012). Biosecurity measures to prevent influenza occurrence in the herds, as well as reducing noninfectious cofactors (environmental factors, handling, stress, and higher infection pressure) are important measures to avoid viral dissemination, in addition to reduce infections by other important respiratory pathogens at this phase (FAO 2010, Barcellos et al. 2017). These were also observed in the present study, as, along with the reduction of swine influenza from 2012 to 2013, a concomitant decrease of bacterial pneumonias was also observed in growingfinishing pigs. Nowadays, swine influenza A virus is frequently found in postweaning pigs in association with Glaesserella (Haemophilus) parasuis, and in finishing pigs in association with Mycoplasma hyopneumoniae and Pasteurella multocida (Barcellos et al. 2017). In Brazil, bacterial pneumonias are important conditions diagnosed in growing and finishing pigs owing to the intensive production systems employed, which are characterized by high animal farming densities in addition to mixture of animal lots with distinct origins (Opriessnig et al. 2011, Mores et al. 2015). The prevalence of this condition varies from 19 to $79 \%$ of the diagnoses in pigs, and, among the bacterial agents, $P$. multocida, $M$. hyopneumoniae, and Actinobacilus pleuropneumoniae are highlighted (Enoe et al. 2002, Fraile et al. 2010, Meyns et al. 2011, Morés et al. 2015). In this study, suppurative bronchopneumonia accounted for $79.6 \%$ of the cases of bacterial pneumonias, which is similar to a previous result (77.3\%) obtained by Mores et al. (2015) in Brazil. These authors have also highlighted from an immunohistochemical and bacterial isolation analysis perspective that $80.3 \%$ and $56.7 \%$ of these cases were caused, respectively, by $M$. hyopneumoniae and $P$. multocida, suggesting that these agents were often coinfecting the pigs. Fibrinonecrotizing pleuropneumonia accounted for $20.4 \%$ of the cases, and these conditions are frequently caused by $A$. pleuropneumoniae infection, as well as are associated with the production of four bacterial exotoxins (ApxI, ApxII, ApxIII, and ApxIV) (Kamp et al. 1997, Opriessnig et al. 2011, Gottschalk 2012a).

Lawsonia intracellularis proliferative enteropathy, Salmonella spp. enterocolitis, and Brachyspira spp. colitis are important worldwide distributed conditions in growing-finishing pigs with similar clinical and pathological features (Jacobson et al. 2003, Suh \& Song 2005, Kich et al. 2011, Viott et al. 2013, Burrough 2016). These conditions represented $10.5 \%$ of the diagnoses in the present study, which are unequal to previous results of $31.7 \%$ and $15.4 \%$ in South Korea and Argentina, respectively (Suh \& Song 2005, Pelliza et al. 2007). Lawsonia spp. enteropathy and Salmonella spp. enterocolitis were endemic diseases in the current work with a frequency of $43.7 \%$ and $41.7 \%$, respectively, when enteric diseases were analyzed. Kich et al. (2011) and Jacobson et al. (2003) have reported results of $39 \%$ and $67 \%$ for Salmonella spp. and $L$. intracellularis isolation from samples of pigs with diarrhea and poor development, which are, respectively, below and above to the ones obtained in this study. Although Brachyspira spp. colitis presented an overall low frequency of diagnosis, a higher incidence was observed from 2010 to 2014. Two possible explanations may be applied to this increase in number of cases of Brachyspira spp. colitis: it may be related to a bacterial resistance to some of the antimicrobials commonly applied to control clinical disease; or it may have occurred due to the introduction of clinically health females, which could have carried subclinical infections to many sow farms of different integration companies (Daniel et al. 2013, Daniel et al. 2017). Strains of Brachyspira spp. resistant to commonly used antimicrobials have been detected in several studies (Duinhof et al. 2008, Pringle et al. 2012), and, recently, in Brazil in a investigation that evaluated the sensitivity of Brachyspira hyodysenteriae and Brachyspira pilosicoli to different classes of antimicrobials (Daniel et al. 2017). Brachyspira species may survive in organic material, such as feces diluted in water, for as long as 48 days in environmental temperatures ranging from 0 to $10^{\circ} \mathrm{C}$ (Hampson \& Burrough 2019); however, this study has detected a higher incidence of clinical disease during spring/summer, which may have occurred because of a higher infection pressure, as well as due to problems of bay drainage and asymptomatic pigs acting as carriers and infection sources (Hampson \& Burrough 2019). 
Polyserositis results with significant economic impact in swine industry owing to increased mortality indexes and carcass condemnation at slaughterhouses (Kang et al. 2012, Uzal et al. 2016). In this study, these lesions corresponded to $5.8 \%$ of the diagnoses, and presented an enzootic distribution along the analyzed years, corroborating with previous data (Nedbalcova et al. 2006, Uzal et al. 2016). Moreover, a previous study by Kang et al. (2012) identified G. (H.) parasuis (85\%), Streptococcus suis (10.7\%), and Mycoplasma hyorhinis (3.6\%) as the main causes of polyserositis in growing-finishing pigs. The low frequency of this condition may be explained by the infection dynamics of $G$. $(H$.$) parasuis in swine, since this infection occurs$ mainly at the postweaning phase in pigs from 4 to 8 weeks of age, wherein there is a decay of colostrum passive immunity (Oliveira \& Pijoan 2004, Nedbalcova et al. 2006).

Suppurative meningitis in pigs is frequently associated with acute infections by Streptococcus suis serotype 1 and 2 (Cantile \& Youssef 2016). The condition is usually related to neurological clinical signs in 5-10-weeks old piglets (Gottschalk 2012b, Cantile \& Youssef 2016), which may justify the low frequency of diagnosis of this condition in the present work (2.3\%), as all animals were older than 63 days. Etiological diagnosis was not obtained in this study because samples were previously fixed in 10\% formalin; even though, the association of the epidemiological and pathological features (suppurative meningitis) led us to believe that these cases are, indeed, related to S. suis. G. (H.) parasuis is another common agent associated with suppurative meningitis in pigs (Oliveira \& Pijoan 2004); however, fibrinosuppurative polyserositis is a classical lesion in this condition, and, only, in severe cases the meninges are involved (Nedbalcova et al. 2006).

\section{CONCLUSIONS}

Infectious diseases accounted for $75.6 \%$ of the diagnoses in growing-finishing pigs in Southern Brazil.

Although PCV2 is considered an important agent detected, a significant reduction of the frequency of cases has been detected as commercially available vaccines were employed since 2008 in Southern Brazil.

Among respiratory diseases, swine influenza A infection was highlighted, reaching a higher frequency at 2012, and, nowadays, it represents the main respiratory disease in pigs along with bacterial bronchopneumonia.

Lawsonia spp. proliferative enteropathy and Salmonella spp. enterocolitis had an endemic distribution among all years of the present study, while Brachyspira spp. colitis had a higher frequency from 2010 to 2014.

Polyserositis and bacterial meningitis had a low frequency of diagnosis with an endemic distribution along the 12 years of this study.

Acknowledgments.- The authors are thankful to the "Coordenação de Aperfeiçoamento de Pessoal de Nível Superior" (CAPES), to the "Conselho Nacional de Desenvolvimento Científico e Tecnológico" (CNPq), and to the remaining researchers of the "Setor de Patologia veterinária" (UFRGS) for obtaining some of the data from this study.

Conflict of interest statement.- The authors declare no conflicts of interest with respect to publication of this manuscript. The authors received no specific grants from any funding agency in the public, commercial or notfor-profit sector for the preparation of this manuscript.

\section{REFERENCES}

Allan G.M. \& Ellis J.A. 2000. Porcine circoviruses: a review. J. Vet. Diagn. Invest. 12(1):3-14. <http://dx.doi.org/10.1177/104063870001200102> <PMid:10690769>

Amaral A.L., Silveira P.R.S., Lima G.J.M.M., Klein C.S., Paiva D.P., Martins F., Kich J.D., Ciacci-Zanella J.R., Favero J., Ludke J.V., Bordin L.C., Miele M., Higarashi M.M., Mores N., Costa O.A.D., Oliveira P.A.V., Bertol T.M. \& Silva V.S. 2006. Boas práticas de produção de suínos. Circular Técnica 50, Embrapa Suínos e Aves, Concórdia, SC. 60p.

Barcellos D.E.S.N., Takeuti K.L., Almeida L.L. \& Oliveira Filho J.X., 2017. Interação entre agentes infecciosos bacterianos e virais no complexo de doenças respiratórias dos suínos, p.133-143. In: Barcellos D., Bortolozzo F.P., Wentz I., Bernardi M.L., Mellagi A.P.G. \& Ulguim R.R. (Eds), Avanços em Sanidade, Produção e Reprodução de Suínos. $2^{2}$ e ed. UFRGS, Porto Alegre, RS.

Brasil 2018. Suínos. Departamento de Defesa Animal, Secretaria de Defesa Agropecuária, Ministério da Agricultura, Pecuária e Abastecimento (MAPA), Brasília, DF.

Brum J.S., Konradt G., Bazzi T., Fighera R.A., Kommers G.D., Irigoyen L.F. \& Barros C.S.L. 2013. Características e frequência das doenças de suínos na Região Central do Rio Grande do Sul. Pesq. Vet. Bras. 33(10):1208-1214. <http://dx.doi.org/10.1590/S0100-736X2013001000006>

Burrough E.R. 2016. Swine dysentery: etiopathogenesis and diagnosis of a reemerging disease. Vet. Pathol. 54(1):1-10. <http://dx.doi. org/10.1177/0300985816653795>

Cantile C. \& Youssef S. 2016. Nervous system, p.250-406. In: Maxie M.G. (Ed.), Jubb, Kennedy and Palmer's Pathology of Domestic Animals. Vol.1. 6th ed. Academic Press, New York. 798p.

Ciacci-Zanella J.R. 2017. Situação atual da circovirose no Brasil. Anais XVIII Congresso da Abraves, Goiânia, GO, p.150-156.

Ciacci-Zanella J.R., Schaefer R., Gava D., Mores N. \& Barcellos D. 2015. Novos conhecimentos sobre a infecção por PCV2 e a emergência de novas estirpes virais. Avanços em Sanidade, Produção e Reprodução de Suínos, Anais do IX Simpósio Internacional de Suinocultura (SINSUI), Porto Alegre, RS.

Daniel A.G.S, Sato J.P.H., Gabardo M.P., Resende T.P., Barcellos D.E.S.N., Pereira C.E.R, Vannucci F.A. \& Guedes R.M.C. 2017. Minimum inhibitory concentration of Brazilian Brachyspira hyodysenteriae strains. Pesq. Vet. Bras. 37(4):331338. <http://dx.doi.org/10.1590/s0100-736x2017000400006>

Daniel A.G.S., Sato J.P.H., Resende T.P. \& Guedes R.M.C. 2013. Infecção por Brachyspira sp. em suínos no Brasil. VIII Simpósio Internacional de Suinocultura (SINSUI), Porto Alegre, RS, p.131-140.

Duinhof T.F., Dierikx C.M., Koene M.G., Van Bergen M.A., Mevius D.J., Veldman K.T., Van Beers-Schreurs H.M. \& De Winne R.T. 2008. Multiresistant Brachyspira hyodysenteriae in a Dutch sow herd. Tijdschr. Diergeneeskd. 133(14/15):604-608. <PMid:18767301>

Enoe C., Mousing J., Schirmer A.L. \& Willeberg P. 2002. Infectious and rearingsystem related risk factors for chronic pleuritis in slaughter pigs. Prev. Vet. Med. 54(4):337-349. <http://dx.doi.org/10.1016/s01675877(02)00029-6><PMid:12163250>

FAO 2010. Global Animal Disease Information System. Food and Agriculture Organization of the United Nations. Availablde at <http://empres-i.fao. org/empres-i/home> Accessed on Jul. 2018.

Fraile L., Alegre A., López-Jiménez R., Nofrarías M. \& Segalés J. 2010. Risk factors associated with pleuritis and cranio-ventral pulmonary consolidation in slaughter-aged pigs. Vet. J. 184(3):326-333. <http://dx.doi.org/10.1016/j. tvjl.2009.03.029><PMid:19527939>

Gillespie J., Opriessnig T., Meng X.J., Pelzer K. \& Buechner-Maxwell V.2009. Porcine circovirus type 2 and porcine circovirus-associated disease. J. Vet. Intern. Med. 23(6):1151-1163. <http://dx.doi.org/10.1111/j.1939-1676.2009.0389.x> <PMid:19780932> 
Gottschalk M. 2012a. Actinobacillosis, p.653-669. In: Zimmerman J.J., Karriker L.A., Ramirez A., Schwartz K.J. \& Stevenson G.W. (Eds), Diseases of Swine. 10th ed. Iowa State University Press, Ames.

Gottschalk M. 2012b. Streptococcosis, p.841-855. In: Zimmerman J.J., Karriker L.A., Ramirez A., Schwartz K.J. \& Stevenson G.W. (Eds), Diseases of Swine. 10th ed. Iowa State University Press, Ames.

Hampson D.J. \& Burrough E.R. 2019. Brachyspiral colitis, p.951-970. In: Zimmerman J.J., Karriker L.A., Ramirez A., Schwartz K.J. \& Stevenson G.W. (Eds), Diseases of Swine. 11th ed. Wiley-Blackwell, Ames.

Hofshagen M., Gjerset B., Er C., Tarpai A., Brun E., Dannevig B., Bruheim T., Fostad I.G., Iversen B., Hungnes O. \& Lium B. 2009. Pandemic influenza A(H1N1)v: human to pig transmission in Norway? Euro Surveill. 14(45):p.13. <http://dx.doi.org/10.2807/ese.14.45.19406-en><PMid:19941789>

Holyoake P.H., Kirkland P.D., Davis R.J., Arzey K.E., Watson J., Lunt R.A., Wang J., Wong F., Moloney B.J. \& Dunn S.E. 2011. The first identified case of pandemic H1N1 influenza in pigs in Australia. Aust. Vet. J. 89(11):427-431. <http://dx.doi.org/10.1111/j.1751-0813.2011.00844.x> $<$ PMid:22008120>

Howden K.J., Brockhoff E.J., Caya F.D., McLeod L.J., Lavoie M., Ing J.D., Bystrom J.M., Alexandersen S., Pasick J.M., Berhane Y., Morrison M.E., Keenliside J.M., Laurendeau S. \& Rohonczy E.B. 2009. An investigation into human pandemic influenza virus (H1N1) 2009 on an Alberta swine farm. Can. Vet. J. 50(11):1153-1161. <PMid:20119537>

Jacobson M., Hard af Segerstad C., Gunnarsson A., Fellstrom C., Verdier Klingenberg K., Wallgren P. \& Jensen-Waern M. 2003. Diarrhea in the growing pig: a comparison of clinical, morphological and microbial findings between animals from good and poor performance herds. Res. Vet. Sci. 74(2):163-169. <http://dx.doi.org/10.1016/s0034-5288(02)00187-x> $<$ PMid:12589741>

Kamp E.M., Stockhofe-Zurwieden N., Van Leengoed L.A. \& Smits M.A. 1997. Endobronchial inoculation with Apx toxins of Actinobacillus pleuropneumoniae leads to pleuropneumonia in pigs. Infect. Immunol. 65(10):4350-4354. <http://dx.doi.org/10.1128/IAI.65.10.4350-4354.1997><PMid:9317048>

Kang I., Kim D., Han K., Seo H.W, Oh Y., Park C., Lee J., Gottschalk M. \& Chae C. 2012. Optimized protocol for multiplex nested polymerase chain reaction to detect and differentiate Haemophilus parasuis, Streptococcus suis, and Mycoplasma hyorhinis in formalin-fixed, paraffin-embedded tissues from pigs with polyserositis. Can. J. Vet. Res. 76(3):195-200. <PMid:23277698>

Kich J.D. \& Cardoso M. 2012. Salmonelose, p.257-264. In: Sobestiansky J., Barcellos, D. (Eds), Doenças dos Suínos. Cânone Editorial, Goiânia, GO.

Kich J.D., Coldebella A., Morés N., Nogueira M.G., Cardoso M., Fratamico P.M., Call J.E., Fedorka-Cray P., Luchansky J.B. 2011. Prevalence, distribution, and molecular characterization of Salmonella recovered from swine finishing herds and a slaughter facility in Santa Catarina, Brazil. Int. J. Food Microbiol. 151(3):307-313.<http://dx.doi.org/10.1016/j.ijfoodmicro.2011.09.024> $<$ PMid:22024043>

Konradt G., Cruz R.A., Bassuino D.M., Bianchi M.V., Andrade C.P., Silva F.S., Driemeier D. \& Pavarini S.P. 2018. Granulomatous necrotizing myositis in swine affected by Porcine Circovirus Disease. Vet. Pathol. 55(2):268-272. <http://dx.doi.org/10.1177/0300985817736114> <PMid:29050543>

Maes D., Verbeke W., Vicca J., Verdonck M. \& De Kruif A. 2003. Benefit to cost of vaccination against Mycoplasma hyopneumoniae in pig herds under Belgian market conditions from 1996 to 2000. Livest. Prod. Sci. 83(1):8593. <http://dx.doi.org/10.1016/S0301-6226(03)00039-3>

Meyns T., Van Steelant J., Rolly E., Dewulf J., Haesebrouck F. \& Maes D. 2011. A cross-sectional study of risk factors associated with pulmonary lesions in pigs at slaughter. Vet. J. 187(3):388-392.<http://dx.doi.org/10.1016/j. tvjl.2009.12.027><PMid:20122861>

Moreno A., Di Trani L., Alborali L., Vaccari G., Barbieri I., Falcone E., Sozzi E., Puzelli S., Ferri G. \& Cordioli P. 2010. First pandemic H1N1 outbreak from a pig farm in Italy. Open Virol. J. 4:52-56. <http://dx.doi.org/10.2174/18 74357901004010052><PMid:20648221>

Mores M.A.Z., Oliveira Filho J.X., Rebelatto R., Klein C. S., Barcellos D. E. N., Coldebella A., \& Morés N. 2015. Aspectos patológicos e microbiológicos das doenças respiratórias em suínos de terminação no Brasil. Pesq. Vet. Bras. 35(8):725-733. <http://dx.doi.org/10.1590/S0100-736X2015000800004>

Morés N. 2009. Torção do mesentério ou síndrome hemorrágica intestinal: qual a importância, como reconhecer, quais as causas e como controlar as perdas causadas. Acta Scient. Vet. 37(supl.1):s11-s15.

Nedbalcova K., Satran P., Jaglic Z., Ondriasova R. \& Kucerova Z. 2006. Haemophilus parasuis and Glässer's disease in pigs: a review. Vet. Med. 51(5):168-179.

Neumann E.J. 2012. Disease transmission and biosecurity, p.141-164. In: Zimmerman J.J., Karriker L.A., Ramirez A., Schwartz K.J. \& Stevenson G.W. (Eds), Diseases of Swine. 10th ed. Iowa State University Press, Ames.

Njabo K.Y., Fuller T.L., Chasar A., Pollinger J.P., Cattoli G., Terregino C., Monne I., Reynes J.M., Njouom R. \& Smith T.B. 2012. Pandemic A/H1N1/2009 influenza virus in swine, Cameroon, 2010. Vet. Microbiol. 156(1/2):189192. <http://dx.doi.org/10.1016/j.vetmic.2011.09.003><PMid:21963416>

Oliveira S. \& Pijoan C. 2004. Haemophilus parasuis: new trends on diagnosis, epidemiology and control: review. Vet. Microbiol. 99(1):1-12. <http:// dx.doi.org/10.1016/j.vetmic.2003.12.001> <PMid:15019107>

Opriessnig T., Giménez-lirola L.G., Halbur P.G. 2011. Polymicrobial respiratory disease in pigs. Anim. Health Res. Rev. 12(2):133-148. <http://dx.doi. org/10.1017/S1466252311000120> <PMid: 22152290>

Opriessnig T., Meng X.J. \& Halbur P.G. 2007. Porcine circovirus type 2 associated disease: update on current terminology, clinical manifestations, pathogenesis, diagnosis, and intervention strategies. J. Vet. Diagn. Invest. 19(6):591-615. <http://dx.doi.org/10.1177/104063870701900601> $<$ PMid:17998548>

Pasma T. \& Joseph T. 2009. Pandemic (H1N1) 2009 infection in swine herds, Manitoba, Canada. Emerg. Infect. Dis.16(4):706-708. <http://dx.doi. org/10.3201/eid1604.091636><PMid:20350394 >

Pelliza B.R., Carranza A.I., Di Cola G. \& Ambrogi A. 2007. Monitoramento das patologias em suínos no período de crescimento. Arq. Bras. Med. Vet. Zootec. 59(3):614-620. <http://dx.doi.org/10.1590/S0102-09352007000300010>

Pereda A., Cappuccio J., Quiroga M.A., Baumeister E., Insarralde L., Ibar M., Sanguinetti R., Cannilla M.L., Franzese D., Escobar Cabrera O.E., Craig M.I., Rimondi A., Machuca M., Debenedetti R.T., Zenobi C., Barral L., Balzano R., Capalbo S., Risso A. \& Perfumo C.J. 2010. Pandemic (H1N1) 2009 outbreak on pig farm, Argentina. Emerg. Infect. Dis. 16(2):304-307.<http://dx.doi. org/10.3201/eid1602.091230><PMid:20113566>

Pringle M., Landén A., Unnerstad H.E., Molander B. \& Bengtsson B. 2012. Antimicrobial susceptibility of porcine Brachyspira hyodysenteriae and Brachyspira pilosicoli isolated in Sweden between 1990 and 2010. Acta Vet. Scand. 54:54. <http://dx.doi.org/10.1186/1751-0147-54-54> $<$ PMid:22998753>

Rech R.R., Gava D., Silva M.C., Fernandes L.T., Haach V., Ciacci-Zanella J.R. \& Schaefer R. 2018. Porcine respiratory disease complex after the introduction of H1N1/2009 influenza virus in Brazil. Zoonoses Public Health 65(1):155161. <http://dx.doi.org/10.1111/zph.12424><PMid:29139241>

Schaefer R., Rech R.R., Silva M.C., Gava D. \& Ciacci-zanella J.R. 2013. Orientações para o diagnóstico de influenza em suínos. Pesq. Vet. Bras. 33(1):61-73. <http://dx.doi.org/10.1590/S0100-736X2013000100012>

Schaefer R., Zanella J.R.C., Brentano L., Vincent A.L., Ritterbusch G.A., Silveira S., Caron L. \& Mores N. 2011. Isolation and characterization of a pandemic H1N1 influenza virus in pigs in Brazil. Pesq. Vet. Bras. 31(9):761-767. <http://dx.doi.org/10.1590/S0100-736X2011000900007>

Segalés J. 2012. Porcine circovirus type 2 (PCV2) infections: clinical signs, pathology and laboratory diagnosis. Virus Res. 164(1/2):10-19. <http:// dx.doi.org/10.1016/j.virusres.2011.10.007> <PMid:22056845> 
Segalés J., Allan G.M. \& Domingo M. 2005. Porcine circovirus diseases. Anim. Health Res. Rev. 6(2):119-142. <http://dx.doi.org/10.1079/ahr2005106> <PMid:16583778>

Sobestiansky J. \& Barcellos D. 2012. Doenças dos Suínos. Cânone Editorial, Goiânia, GO, p.553-580.

Suh D.K. \& Song J.C. 2005. Prevalence of L. intracellularis, B. hyo dysenteriae, and Salmonella in swine Herds. J. Vet. Scie. 6(4):289-293. <PMid:16293991>

Tateyama S., Molina H.A., Uchida K., Yamaguchi R. \& Manuel M.F. 2000. An epizootiological survey of necropsy cases (1993-1997) at University of the Philippines. J. Vet. Med. Sci. 62(4):439-442. <http://dx.doi.org/10.1292/ jvms.62.439><PMid:10823733>

Uzal F.A., Plattner B.L. \& Hostetter J.M. 2016. Alimentary system, p.1-257. In: Maxie M.G. (Ed.), Jubb, Kennedy \& Palmer's Pathology of Domestic Animals. Vol.2. 6th ed. Academic Press, New York. 654p.
Van Reeth K., Brown I.H. \& Olsen C.W. 2012. Influenza virus, p.557-571. In: Zimmerman J.J., Karriker L.A., Ramirez A., Schwartz K.J. \& Stevenson G.W. (Eds), Diseases of swine. 10th ed. Iowa State University Press, Ames.

VanAlstine H.W. 2012. Respiratory system, p.348-362. In: Zimmerman J.J., Karriker L.A., Ramirez A., Schwartz K.J. \& Stevenson G.W. (Eds), Diseases of Swine. 10th ed. Iowa State University Press, Ames.

Viott A.M., Lage A.P., Cruz junior E.C.C., Guedes R.M.C. 2013. The prevalence of swine enteropathogens in Brazilian grower and finish herds. Braz. J. Microbiol. 44(1):145-151. <http://dx.doi.org/10.1590/S1517-83822013005000033> <PMid:24159297>

Watanabe T.T.N., Almeida L.LA., Wouters F., Wouters A.T.B., Zlotowski P. \& Driemeier D. 2012. Histopathological and immunohistochemical findings of swine with spontaneous influenza A infection in Brazil, 2009-2010. Pesq. Vet. Bras. 32(11):1148-1154. <http://dx.doi.org/10.1590/S0100736X2012001100013> 